\title{
Improvements in Non-precoated Indirect Enzyme-linked Immunosorbent Assay for Specific Detection of Three Potyviruses Infecting Cucurbitaceous Plants
}

\author{
Takahide SASAYA* and Takashi YAMAMOTO**
}

\begin{abstract}
Key words: watermelon mosaic virus 2, zucchini yellow mosaic virus, papaya ringspot virus W, serodiagnosis, I-ELISA.
\end{abstract}

Enzyme-linked immunosorbent assay (ELISA) is one of the most useful and simple serodiagnostic techniques and has spread rapidly as a diagnosis of many plant viruses $^{3,4)}$. It has proved most unsatisfactory, however, when applied to the potyviruses, especially closely related viruses ${ }^{2,6)}$, because of the variable cross-reactivity of polyclonal antisera. One example is the case of three potyviruses, watermelon mosaic virus 2 (WMV2), zucchini yellow mosaic virus (ZYMV), and papaya ringspot virus $\mathrm{W}$ (PRSV-W), which are major causal agents of mosaic diseases in cucurbitaceous plants. Previous studies and our preliminary ones showed that the broad specificity of non-precoated indirect enzyme-linked immunosorbent assay (I-ELISA), using polyclonal antisera, gave a misdiagnosis of WMV2 with the other serologically related virus, $Z Y_{M V^{7,8,10} \text {. }}$.

This paper describes improvements of I-ELISA using a cross-absorbed antiserum in order to establish a simple method for serodiagnosis of WMV2, ZYMV, and papaya ringspot virus W (PRSV-W) in cucurbitaceous plants.

WMV2-9(M) ${ }^{11)}$ and ZYMV-42ZY ${ }^{1)}$ were isolated from diseased bur cucumber (Sicyos angulatus) and cucumber (Cucumis sativus) plants each collected in Kagawa Prefecture. PRSV-W-Ch5 ${ }^{1)}$ was isolated from a cucumber plant with mosaic symptoms in Chiba Prefecture. These viruses were purified from systemically infected cucumber or pumpkin leaves according to the methods of Sako et $a l^{5}{ }^{5}$ and of Yonaha et al. ${ }^{12}$ Antisera against each virus $^{1)}$ were generous gifts from Dr. M. Iwasaki. In addition to the three viruses, four other isolates of WMV2 (WULa, Wb-2-1, Wk3-1, W8-2), four other isolates of ZYMV (Z5-1, 4S17a6, Z-UBe, 8(E)), and two other isolates of PRSV-W(H4, P-3), which were generous gifts from Y. Kosaka (Kyoto Agricultural Research Institute), Dr. T. Natsuaki (Faculty of Agriculture, Utsunomiya University) and Dr. T. Yonaha (Faculty of Agriculture, Ryukyu University) were used for detection by I-ELISA.
Pumpkin (Cucurbita pepo) seedlings were grown in a glasshouse at $25^{\circ} \mathrm{C}$ and their cotyledons were mechanically inoculated with WMV2, ZYMV, or PRSV-W. Seven to 10 days after inoculation, systemically infected upper leaves were sampled and stored at $-80^{\circ} \mathrm{C}$ until use. I-ELISA was carried out according to Koenig's method $^{3)}$. Two hundred $\mu 1$ of leaf homogenates in coating buffer ( $0.05 \mathrm{M}$ sodium carbonate, $\mathrm{pH}$ 9.6) was added to the wells of microtiter plates (Immulon 1), which were incubated for $1 \mathrm{hr}$ at $25^{\circ} \mathrm{C}$. Two hundred $\mu 1$ of antisera, diluted with TBST $(20 \mathrm{mM}$ Tris- $\mathrm{HCl}, 0.15 \mathrm{M} \mathrm{NaCl}, \mathrm{pH}$ 7.5 , containing $0.05 \%$ Tween-20) or leaf homogenates, were added to each well and incubated for $1 \mathrm{hr}$ at $25^{\circ} \mathrm{C}$. Two hundred $\mu 1$ of alkaline phosphatase-labeled goat anti-rabbit IgG (Sigma, cat. no. A8025) diluted 1:10 ${ }^{3}$ with TBST was added. After incubation of plates for $1 \mathrm{hr}$ at $25^{\circ} \mathrm{C}, 200 \mu 1$ of $p$-nitrophenyl phosphate in $10 \%$ diethanolamine, $\mathrm{pH} 9.8(1 \mathrm{mg} / \mathrm{ml})$ was added and reactions were determined spectrophotometrically at $405 \mathrm{~nm}$. Plates were washed three times with TBST between each step.

We tested the possibility of detecting WMV2, ZYMV, and PRSV-W in serial dilutions of leaf homogenates (Fig. 1). Antisera against WMV2 and ZYMV could not easily be distinguished by their reactivity between WMV2 and ZYMV because moderately strong crossreactions occurred with antiserum against WMV2 or ZYMV, and vice versa, however, antiserum against PRSV-W did not cross-react with WMV2 and ZYMV.

In order to prevent the cross-reaction found between WMV2 and ZYMV, we used the antisera preincubated with four forms of purified heterologous virus, such as native virus ( $\mathrm{N}$-virus), trypsin-treated virus ( $\mathrm{T}$-virus), pH9.6-denatured virus (pH9.6-virus), and SDS-denatured virus (SDS-virus). The T-virus was prepared by incubating purified virus (at $1 \mathrm{mg} / \mathrm{ml}$ ) with trypsin at a ratio of $2 \mu \mathrm{g}$ of enzyme per $\mathrm{mg}$ of virus for $30 \mathrm{~min}$ at room temperature and this was followed by centrifugation at $78,000 \mathrm{~g}$ for $1.5 \mathrm{hr}$ at $4^{\circ} \mathrm{C}$. The $\mathrm{pH} 9.6$-virus was prepared

* Shikoku National Agricultural Experiment Station, 1-3-1, Senyu-cho, Zentsuji, Kagawa 765, Japan＼cjkstart四国農業試験場

** Chugoku National Agricultural Experiment Station, 6-12-1, Nishifukatsu-cho, Fukuyama, Hiroshima 721, Japan 中国 農業試験場 

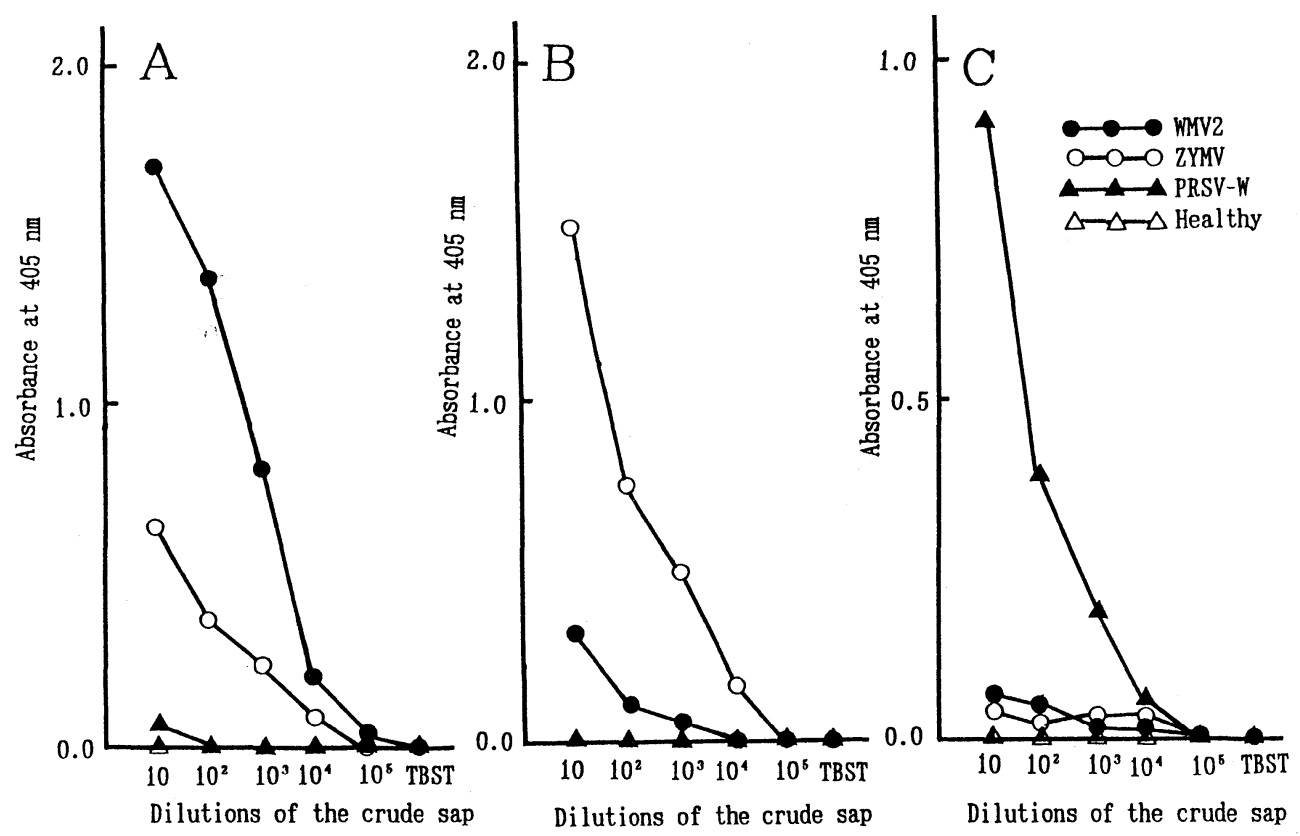

Fig. 1. Detection of WMV2, ZYMV, and PRSV-W in crude homogenates of pumpkin by I-ELISA. Antisera against WMV2(A), ZYMV(B), and PRSV.-W(C) were diluted 1:10 ${ }^{4}, 1: 5 \times 10^{4}$, and $1: 5 \times 10^{3}$, respectively. Each point is the mean of three experiments using three wells in each experiment.
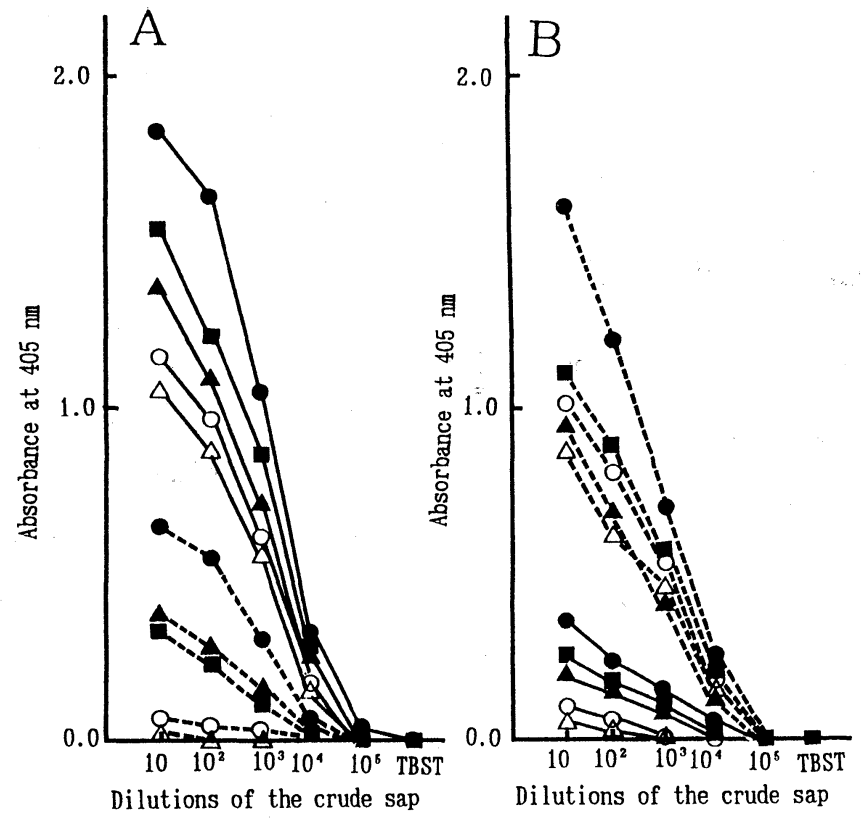

Fig. 2. The effect of preincubating antisera against WMV2 (diluted 1:104) and ZYMV (diluted 1:5× $10^{4}$ ) with four forms of purified heterologous virus in I-ELISA. ELISA absorbance (A $405 \mathrm{~nm}$ ) of WMV2-infected $(-)$ and ZYMV-infected $(\cdot \cdots \cdot$.$) leaf homogenates. Antisera against$ WMV2 (A) and ZYMV(B) were preincubated with TBST alone $(\bullet)$, native virus solution $(\boldsymbol{\square})$, trypsin-treated virus solution ( $\mathbf{\Delta})$, pH 9.6denatured virus solution $(\bigcirc)$, and SDSdenatured virus solution $(\triangle)$. Each point is the mean of three experiments using three wells in each experiment.
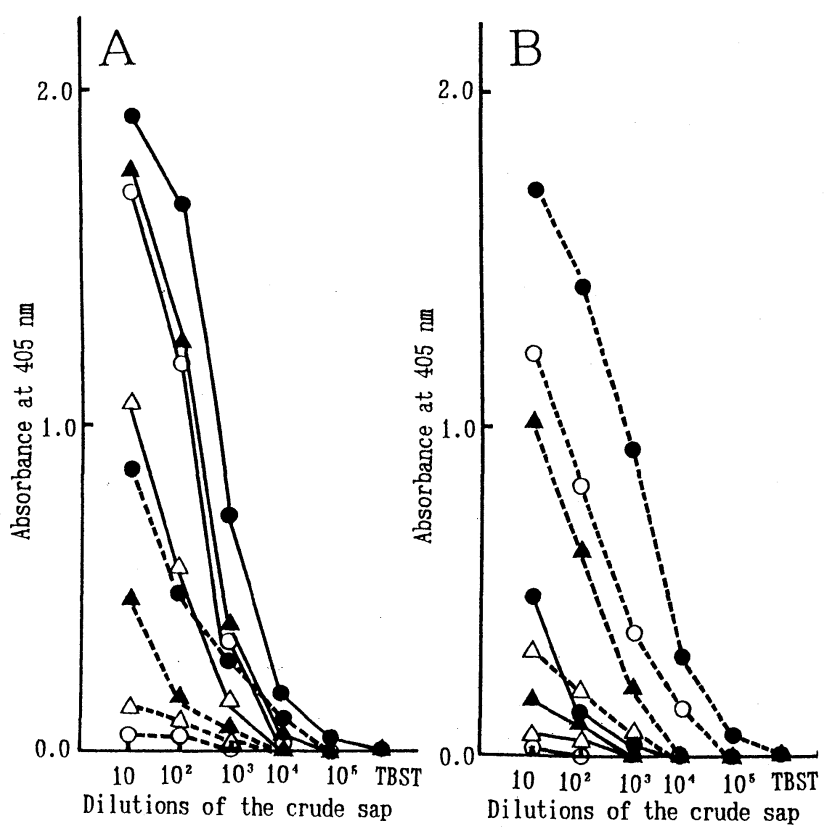

Fig. 3. The effect of diluting antisera against WMV2 (diluted 1:104) and ZYMV (diluted 1:5 $\times 10^{4}$ ) with heterologous virus infected leaf homogenates. ELISA absorbance (A $405 \mathrm{~nm}$ ) of WMV2infected ( $(-)$ and ZYMV-infected ( $\cdots \cdots \cdot$ ) leaf homogenates. Antisera against WMV2 (A) and ZYMV (B) were diluted with healthy homogenate $(\bullet)$, virus-infected homogenate $(\mathbf{\Delta}), \mathrm{pH}$ 9.6-denatured virus-infected homogenate $(\bigcirc)$, and SDS-denatured virus-infected homogenate $(\triangle)$. Each point is the mean of three experiments using three wells in each experiment. 
by incubating purified virus (at $1 \mathrm{mg} / \mathrm{ml}$ ) in the coating buffer for $1 \mathrm{hr}$ at $25^{\circ} \mathrm{C}$ and then dialyzing against TBST. The SDS-virus was prepared from purified virus (at 1 $\mathrm{mg} / \mathrm{ml}$ ) by heating at $56^{\circ} \mathrm{C}$ for $15 \mathrm{~min}$ in TBST containing $0.2 \%$ SDS and then dialyzing against TBST. The antisera diluted with ten-fold the above mentioned virus preparations were incubated for $1 \mathrm{hr}$ at room temperature and the precipitate was removed by centrifugation at $78,000 \mathrm{~g}$ for $1.5 \mathrm{hr}$ at $4^{\circ} \mathrm{C}$.

As the results, in the tests using the antisera incubated with $\mathrm{N}$-virus or T-virus, reciprocal cross-reactions between WMV2 and ZYMV were observed, whereas the incubation with $\mathrm{pH}$ 9.6-virus or SDS-virus completely inhibited the cross-reactions (Fig. 2). These data suggested that the antiserum incubated with the forms of the heterologous viral capsid subunits avoided the crossreactions between WMV2 and ZYMV probably because the subunits absorb antibodies that react cryptotopes commonly conserved in WMV2 and ZYMV ${ }^{8}$.

Secondly, we tested the effect of diluting the antisera against WMV2 and ZYMV with homogenates of pumpkin leaves infected with the heterologous virus in order to establish a more simple method to cross-absorb the antisera (Fig. 3). The antiserum was preincubated with homogenates of healthy leaves (H-homogenate) or three homogenates of virus-infected leaves, such as native homogenate (N-homogenate), $\mathrm{pH}$ 9.6-denatured homogenate ( $\mathrm{pH}$ 9.6-homogenate), and SDS-denatured homogenate (SDS-homogenate) for more than one hour at room temperature. For preparation of the H-homogenate and the $\mathrm{N}$-homogenate, $1.0 \mathrm{~g}$ of healthy pumpkin leaves (H-homogenate) or virus-infected leaves (N- homogenate) was homogenized in $10 \mathrm{ml}$ of TBST as described by Suzuki et al. ${ }^{9)}$ and clarified by centrifugation at 8,500 $\mathrm{g}$ for $10 \mathrm{~min}$. The $\mathrm{pH} 9.6$-homogenate or the SDS-homogenate was prepared as follows: $1.0 \mathrm{~g}$ of virus-infected pumpkin leaves was homogenized in $10 \mathrm{ml}$ of the coating buffer ( $\mathrm{pH}$ 9.6-homogenate) or TBST containing $0.2 \%$ SDS (SDS-homogenate), clarified by centrifugation at $8,500 \mathrm{~g}$ for $10 \mathrm{~min}$, and then dialyzed against TBST.

The same tendency was observed in the case of the antiserum preincubated with purified virus preparation. That is, the $\mathrm{pH}$ 9.6- and SDS-homogenates were helpful to completely inhibit the reciprocal cross-reactions between WMV2 and ZYMV, whereas the $\mathrm{H}$ - and $\mathrm{N}$ homogenates were not. It should be noted that homologous as well as heterologous reactions with the antiserum diluted with the SDS-homogenate were inhibited remarkably.

We applied this method for detecting four other isolates of WMV2, four other isolates of ZYMV and two other isolates of PRSV-W (Table 1). The antiserum against WMV2 diluted with the H-homogenate, strongly reacted with five isolates of WMV2 and weakly crossreacted with five isolates of $Z Y M V$, but did not crossreact with three isolates of PRSV-W. In the tests using the antiserum diluted with the $\mathrm{pH}$ 9.6-homogenate, however, these reciprocal cross-reactions were completely abolished. Likewise, the antiserum against ZYMV diluted with the H-homogenate, weakly cross-reacted with five isolates of WMV2, whereas the antiserum diluted with the $\mathrm{pH}$ 9.6-homogenate was not reactive with five isolates of WMV2. The antiserum against PRSV-W

Table 1. Detection of WMV2, ZYMV, and PRSV-W in crude homogenates of pumpkin by I-ELISA

\begin{tabular}{|c|c|c|c|c|c|c|}
\hline & & \multicolumn{4}{|c|}{ Antisera } & \multirow{3}{*}{$\frac{\text { PRSV }-W^{\mathrm{d})}}{\mathrm{H}}$} \\
\hline \multicolumn{2}{|c|}{ Antigens $^{\text {a) }}$} & \multicolumn{2}{|c|}{$\mathrm{WMV}^{\mathrm{b})}$} & \multicolumn{2}{|c|}{$Z_{Y_{M V}}{ }^{c}$} & \\
\hline & & $\mathrm{H}$ & $Z \mathrm{Y}$ & $\mathrm{H}$ & WM & \\
\hline \multirow[t]{5}{*}{ WMV2- } & $9(\mathrm{M})$ & $1.77^{\mathrm{e})}$ & 1.81 & 0.13 & 0.03 & 0.04 \\
\hline & WULa & 2.35 & 1.86 & 0.20 & 0.03 & 0.07 \\
\hline & Wb-2-1 & 2.38 & 1.92 & 0.41 & 0.06 & 0.04 \\
\hline & Wk3-1 & 2.36 & 1.82 & 0.49 & 0.07 & 0.04 \\
\hline & W8-2 & 2.26 & 1.81 & 0.36 & 0.06 & 0.05 \\
\hline \multirow[t]{5}{*}{ ZYMV- } & $42 Z Y$ & 0.49 & 0.00 & 1.09 & 0.81 & 0.06 \\
\hline & Z5-1 & 0.69 & 0.00 & 1.30 & 0.88 & 0.03 \\
\hline & 4S17a6 & 0.36 & 0.01 & 0.35 & 0.21 & 0.07 \\
\hline & Z-UBe & 0.30 & 0.00 & 0.31 & 0.20 & 0.05 \\
\hline & $8(\mathrm{E})$ & 0.65 & 0.02 & 1.49 & 1.19 & 0.01 \\
\hline \multirow[t]{3}{*}{ PRSV-W- } & Ch5 & 0.00 & 0.00 & 0.00 & 0.00 & 0.75 \\
\hline & $\mathrm{H} 4$ & 0.02 & 0.00 & 0.03 & 0.03 & 1.86 \\
\hline & P-3 & 0.00 & 0.00 & 0.00 & 0.01 & 1.08 \\
\hline Healthy & & 0.00 & 0.00 & 0.00 & 0.01 & 0.01 \\
\hline
\end{tabular}

a) Virus-infected homogenates diluted $1: 10$ with coating buffer were used as antigen.

b) Antiserum against WMV2 was diluted with the $\mathrm{pH}$ 9.6-denatured homogenates of healthy (H) or of ZYMV-infected (ZY) pumpkin leaves.

c) Antiserum against ZYMV was diluted with the pH 9.6-denatured homogenates of healthy (H) or of WMV2-infected (WM) pumpkin leaves.

d) Antiserum aginst PRSV-W was diluted with the $\mathrm{pH}$ 9.6-denatured homogenates of healthy pumpkin leaves (H).

e) Each value was the average of absorbance value at $405 \mathrm{~nm}$ from three experiments using three wells in each experiment. 
diluted with the $\mathrm{H}$-homogenate reacted with only three isolates of PRSV-W, but did not react with the isolates of WMV2 and ZYMV.

The I-ELISA, utilizing the $\mathrm{pH}$ 9.6-denatured homogenate of ZYMV-infected leaves to dilute antiserum against WMV2 and the $\mathrm{pH}$ 9.6-denatured homogenate of WMV2-infected leaves to dilute antiserum against ZYMV, proved to be very effective in eliminating crossreaction between WMV2 and ZYMV. When using these antisera against WMV2, ZYMV, and PRSV-W, respectively, then these viruses could be detected specifically in cucurbitaceous plants.

The authors are grateful to Dr. N. Suzuki, Biotechnology Institute, Akita Prefectural College of Agriculture, for revising the text; Dr. M. Iwasaki, Shikoku National Agricultural Experiment Station, for sending virus antisera; Y. Kosaka, Kyoto Agricultural Research Institute; Dr. T. Natsuaki, Faculty of Agriculture, Utsunomiya University; and Dr. T. Yonaha, Faculty of Agriculture, Ryukyu University, for sending virus isolates.

\section{Literature cited}

1. Iwasaki, M., Yamamoto, T. and Inaba, T. (1988). Wilt of cucumber plants grafted on squash rootstocks caused by viruses. Bull. Shikoku Natl. Agric. Exp. Stn. 59 (in press).

2. Jordan, R. and Hammond, J. (1991). Comparison and differentiation of potyvirus isolates and identification of strain-, virus-, subgroup-specific and potyvirus group common epitopes using monoclonal antibodies. J. Gen. Virol. 72 : 25-36.

3. Koenig, R. (1981). Indirect ELISA methods for the broad specificity detection of plant viruses. J. Gen. Virol. $55: 53-62$.

4. Lommel, S.A., McCain, A.H. and Morris, T.J. (1982). Evaluation of indirect enzyme-linked immunosorbent assay for the detection of plant viruses. Phytopathology 72 : $1018-1022$.

5. Sako, N., Matsuo, K. and Nonaka, F. (1980). Purification of watermelon mosaic virus. Ann. Phytopathol. Soc. Jpn. 46 : 639-646.

6. Shukla, D.D., Strike, P.M., Tracy, S.L., Gough, K.H. and Ward, C.W. (1988). The N and C termini of the coat proteins of potyviruses are surface-located and the $\mathrm{N}$ terminus contains the major virus-specific epitopes. $J$.
Gen. Virol. 69 : 1497-1508.

7. Somowiyarjo, S., Sako, N. and Nonaka, F. (1988). The use of monoclonal antibody for detecting zucchini yellow mosaic virus. Ann. Phytopathol. Soc. Jpn. 54 : 436443.

8. Somowiyarjo, S., Sako, N. and Nonaka, F. (1990). Production and characterization of monoclonal antibodies to watermelon mosaic virus 2. Ann. Phytopathol. Soc. Jpn. 56 : 541-548.

9. Suzuki, N., Shirako, Y. and Ehara, Y. (1990). A simple method for elimination of non-specific reactions in nonprecoated indirect and electroblot enzyme-linked immunosorbent assay procedures used for detection of zucchini yellow mosaic virus. Ann. Phytopathol. Soc. Jpn. $56:$ 337-341.

10. Suzuki, N., Shirako, Y. and Ehara, Y. (1990). Isolation and serological comparison of virus-coded proteins of three potyviruses infecting cucurbitaceous plants. Intervirology $31: 43-49$.

11. Yamamoto, T., Ishii, M. and Katsube, T. (1982). Serological grouping of watermelon mosaic virus isolates. Ann. Phytopathol. Soc. Jpn. 48 : 613-619.

12. Yonaha, T., Tamori, M., Negawa, M., Kuwae, T. and Kubura, A. (1977). Two watermelon mosaic virus strains isolated from mosaic diseased muskmelon and squash. Sci. Bull. Coll. Agr. Univ. Ryukyus 24 : 181-190 (in Japanese).

\section{和 文 摘 要}

笹谷孝英・山本孝狶：ウリ類に発生する 3 種 potyvirus を特 異的に検出するための間接 ELISA の改良

間接-ELISA 用いてウリ類に発生する 3 種の potyvirus （カボチャモザイクウイルス：WMV2, ズッキーニ黄斑モザイ クウイルス : ZYMV, パパイア輪点ウイルス-W : PRSV-W)を 検出する場合は，3 種の抗血清は異種ウイルスにも反応を示す。 特にWMV2の抗血清はZYMVに, ZYMVの抗血清は WMV2 と強く反応を示し, 両ウイルスの識別が困難である。こ の交差反応をなくすため異種ウイルスで抗血清を吸収すること を試みた。そこで, 異種ウイルスの純化試料を $0.05 \mathrm{M}$ 炭酸ナト リウム緩衝液 (pH 9.6) で処理したもの，あるいは感染葉を 0.05 $\mathrm{M}$ 炭酸ナトリウム緩衝液（pH 9.6）で磨砕し，0.02 M トリス緩 衝液 (pH 7.5) で透析したもので，抗血清を希釈して用いるとこ の交差反応は抑えられ, 本法により WMV2, ZYMV, PRSV-W を特異的に検出することが可能となった。

(Received October 27, 1994 ; Accepted December 27, 1994) 